\title{
TALENT MANAGEMENT PRACTICES ON EMPLOYEE TURNOVER INTENTION
}

\author{
Wehelmina Rumawas \\ Department of Administration, Faculty of Social and Political Science, Sam Ratulangi University \\ Manado, Indonesia \\ Address: Jalan Kampus Unsrat, Manado-Sulawesi Utara, Indonesia 95115 \\ E-mail: feibyrumawas@unsrat.ac.id
}

\begin{abstract}
Human resource managers need to play critical roles to overcome the talented and younger employees' turnover intention in an organization. This study aims to determine the causal relationship between talent management practice, perceived organizational support, and employee engagement and the impact on the turnover intention of Generation Y employees. A convenience sampling technique was used for this research. The study surveyed 182 Generation Y employees. The data collected were initially analyzed using the PLS-SEM method with the smartPLS-3 software. The results showed that talent management practice has a significant effect on perceived organizational support and employee engagement. It is also inferred that talent management practice, perceived organizational support, and employee engagement has a significant negative effect on turnover intention. This study also confirms that perceived organizational support has a significant positive effect on employee engagement. Additionally, this study discovered that perceived organizational support and employee engagement operate as mediators between talent management practices and turnover intention.
\end{abstract}

Keywords: Employee engagement, generation Y, organizational support, talent management, turnover intention

JEL Classification: M12

Article History:

Received: August 25, 2021; Revised: November 3, 2021; Accepted : November 10, 2021; Available Online :

December 12, 2021

DOI: 10.20473 /imtt.v1 4 i3.29433

\section{INTRODUCTION}

Employees leaving an organization are psychologically painful for both the organization and its other employees: a professional setback. It has a detrimental effect on the social life of the organization (Ghosh et al., 2013). There is also empirical evidence suggesting that organizations have to endure higher financial costs due to employee turnover (Sandhya and Sulphey, 2021). According to a 2012-2013 Tower Watson survey of global employers, $50 \%$ have difficulty retaining top performers. This figure rises to $55 \%$ for high potential employees and $56 \%$ for employees with skills related to the organization's strategic competencies (León and García-Saavedra, 2019). Riendl, (2007) stated that the development, attraction, and retention of talent through effective talent management ensure superiority in the marketplace and an upsurge in the organization's inclusive financial performance. According to some surveys, Generation Y members are likely to change jobs every two years to find new challenges and 
experiences. As a result, Generation Y has developed a reputation for professional mobility and a high turnover rate within organizations (Du Plessis et al., 2015).

High employee turnover is a common and expensive problem in the banking industry (Islam et al., 2013; Suliman and Al Obaidli, 2011). The same is true for the Indonesian banking industry. Problems such as low income, unreasonable working hours, tedious work schedules, and inadequate career opportunities are the reasons for high turnover rates (Gupta, 2019). Employers will face substantial issues in retaining the top talent among Generation Y graduates if they are unwilling to adjust or adapt their human resource policies. As a result, talent management processes to fit the new generation (Guthridge, Komm and Lawson, 2008). Banking organizations should devise and pursue efficient methods for reducing staff turnover. Thus, researchers must understand the relationship between Generation Y employees' perceptions of an organization's talent management practices, organizational support, and employee engagement and the impact on their intention to quit.

Previous research examined the relationship between talent management practices and turnover intention (Bui and Chang, 2018; Du Plessis et al., 2015; Gupta, 2019; León and GarcíaSaavedra, 2019). These research studies have found a negative correlation between talent management practice and employee turnover intention. Against this background, the primary objective of this study is to determine whether there is a causal relationship between perceived talent management methods, perceived organizational support, employee engagement, and Generation $Y$ employees' intention to leave. This study believes that examining these constructs will provide the organization with valuable information into the causes of employee turnover and the capability to develop a valuable talent retention model for Generation Y.

\section{LITERATURE REVIEW AND HYPOTHESES}

\section{Talent Management Practices}

The potential significance of talent management in distinguishing between high and lowperforming organizations has become a primary priority for organizations due to the scarcity of qualified people (Anlesinya, Amponsah-Tawiah and Dartey-Baah, 2019). The phrase McKinsey and Company first used talent management in the late 1990s. It is the sum of an individual's capabilities, experiences, competencies, attitudes, and behavior that may be translated into organizational performance (Du Plessis et al., 2015). Human resources placed a premium on talent management as a global-local endeavor to guarantee that strategic and operational decisions and functional human resource operations were oriented towards gaining competitive advantage through people. Talent management can be defined as "a set of long-term organizational strategies that leverage human capital to the organisation's competitive advantage as well as a portfolio of integrated human resource activities that 


\section{Wehelmina Rumawas}

result in the placement of the right people with the right competencies in the right job in the right place and at the right cost" (Claus, 2019). Talent management can be classified as a supportive human resource practice (Du Plessis et al., 2015; Gupta, 2019).

\section{Perceived Organizational Support}

Employees' perceptions of their organization's concern for their well-being and value for their contributions are referred to as perceived organizational support (Guchait, Cho and Meurs, 2015). According to organizational support theory, the positive influence of POS on employee behavior and attitudes develops due to social interactions between employees and the organization (Cao, Hirschi and Deller, 2014). Social exchange theory examines how societies and human behavior develop over time. According to social exchange theory, people evaluate their accomplishments in comparison to other people or institutions. If an individual believes that the organization is well supported, he or she will contribute more to the organization (Akgunduz, Alkan and Gök, 2018).

\section{Employee Engagement}

Employee engagement is defined as an employee's strong emotional and intellectual attachment to his or her job, organization, manager, or co-workers, which motivates him or her to put in extra effort. (Hughes and Rog, 2008). A positive, fulfilling, work-related state of mind characterized by vigor, dedication, and absorption is defined as engagement (Schaufeli et al., 2002). Several studies have emerged to address employee turnover by implementing talent management practices that can significantly contribute to employee engagement and retention (Alias, Nor and Hassan, 2016).

\section{Turnover Intention}

Employee turnover is the voluntary cessation of membership in an organization by an individual who receives monetary compensation for participation (Hom, 2004). Among all the cognitions that contribute to the turnover process, the intention to leave, defined as a person's desire to leave an institution, is the single most powerful and accurate predictor of actual turnover (Wang et al., 2020).

\section{Generation Y}

Generation Y individuals or millennials can be defined as people born between 1980 and 1995 (Basset, 2008). Members of Generation Y have witnessed the birth of the internet, economic liberalization, the popularity of social media, the rise of environmental awareness, and terrorism. Most Generation Y employees are born to financially secure parents and raised in a multicultural, technologically advanced environment (Naim and Lenka, 2018). According to a 2008 survey conducted by PricewaterhouseCoopers (PwC), 88\% of Generation Y employees 
seek out companies who share their values, and $86 \%$ agree to leave employers who fail to achieve their expectations (Zainee and Puteh, 2020).

\section{Conceptual Framework and Hypotheses}

\section{Talent Management Practice and Perceived Organisational Support}

Human resources practices signifying that the organization values and cares for its employees by investing in them and recognizing their efforts imply that the organization supports them (Allen, Shore and Griffeth, 2003). Whitener (2001) argued for the importance of employee perceptions of such human resources practices. Employees may not always perceive the objective existence of certain practices as the organizational desire. For example, an organization may encourage involvement in decision-making and may even establish a formal system for incorporating input. However, suppose employees do not sense that the organization or its agents are open to receiving information and are inclined to act on it. In that case, they are unlikely to feel the organization provides involvement.

Similarly, most firms presumably believe their compensation schemes are relatively fair, yet many employees disagree. Thus, how the firm offers supportive HR policies is likely to influence employee attitudinal and behavioral responses. The previous study has established a positive direct relationship between talent management practices and perceived organizational support, as Du Plessis et al. (2015) and Gupta (2019) demonstrate. As a result, we present the following hypothesis:

Hypothesis 1: The Generation Y employee's perception of the organization's TMP is positively related to POS

\section{Talent Management Practice and Employee Engagement}

Talent management is critical to engaging employees in the organization. The ability to solve both of these concerns effectively has become a crucial driver of organizational performance and, in some cases, survival (Hughes and Rog, 2008). Improving outcomes in winning talented employees' hearts will only come to those organizations that learn to master talent management practices (Alias, Nor and Hassan, 2016). The previous study has established a positive direct relationship between talent management practice and employee engagement, such as research from Bui and Chang (2018). As a result, we suggest the following hypothesis:

Hypothesis 2: The Generation Y employee's perception of the organization's TMP is positively related to $\mathrm{EE}$ 


\section{Talent Management Practice and Turnover Intention}

The concept that talent is synonymous with turnover stems from supply and demand principles. If talent is scarce and valuable, its high demand will act as a continual invitation to seek a better nest (León and García-Saavedra, 2019). The ability of supportive HR practices (which implies Talent Activities) to promote retention argues that these policies are likely to lessen an employee's intention to quit an organization. This can also be related to increased job satisfaction associated with the employee's experience of supportive HR practices (Du Plessis et al., 2015). The previous study has established a negative direct relationship between talent management practice and turnover intention (Bui and Chang, 2018; Du Plessis et al., 2015; Gupta, 2019). Therefore, we suggest the following hypothesis:

Hypothesis 3: The Generation Y employee's perception of the organization's TMP is negatively related to TI

Talent Management Practice, Perceived Organizational Support, and Turnover Intention Employees who believe their organization has treated them well are more likely to feel connected and stay with the organization. On the other hand, if employees believe the organization does not treat them well, they are less likely to stay attached to them (Joo, Hahn and Petersonb, 2015). People with the notion that the company they work for cares and supports them will be less convinced to hunt for alternate employment, further minimizing employee turnover (Gupta, 2019). According to previous research, employees with a high POS are less likely to seek and accept alternative jobs (Joo et al., 2015). In addition, Du Plessis et al. (2015) and Gupta (2019) have found that POS cannot act as the mediator of TMP and Turnover Intention. Therefore, we present the following hypothesis:

Hypothesis 4: There is a negative correlation between the Generation Y employee's POS and TI.

Hypothesis 5: POS does not mediate the correlation between the Generation Y employee's perception of the organization's TMP and TI.

\section{Talent Management Practice, Employee Engagement, and Turnover Intention}

Alias et al. (2016) revealed that employee engagement could reduce employee turnover intention. According to Sibiya et al. (2014), if engagement is experienced in the organization, employees tend to remain with the organization, which results in a lower turnover. The higher engagement was found to promote favorable attitudes towards work and organization and job satisfaction, organizational commitment, and low turnover intention (Sandhya and Sulphey, 2021). Previous studies (Bui and Chang, 2018; Kim and Hyun, 2017; Memon et al., 2020; Sibiya et al., 2014) have found that employee engagement has a direct negative effect on 
turnover intention. In addition, Bui and Chang (2018) have found that EE can act as the mediator of TMP and Turnover intention. As a result, we present the following hypothesis:

Hypothesis 6: There is a negative correlation between the Generation $Y$ employees' perceived EE and TI.

Hypothesis 7: EE mediates the correlation between the Generation $Y$ employee's perception of the organization's TMP and TI.

\section{Perceived Organizational Support and Employee Engagement}

When employees perceive that their employer is worried about them and cares about their well-being, they are likely to respond by seeking to fulfill their commitments to the firm by becoming more engaged (Saks, 2006). A positive relationship between POS and EE shows that higher levels of EE are a response to POS, which is conceived as employees' impressions of the degree to which their organization values their contributions and cares about their well-being (Musenze et al., 2020). Various studies have found a positive direct relationship between perceived organizational support and employee engagement (Nazir and Islam, 2017; Musenze et al., 2020). Therefore, we suggest the following hypothesis:

Hypothesis 8: The Generation Y employees perceived POS is positively related to EE.

Following the literature assessment and formulation of hypotheses, an integrated conceptual model is developed in which the interactions between the constructs can be studied. It is illustrated in Figure 1, with Generation Y employees serving as the study's setting.

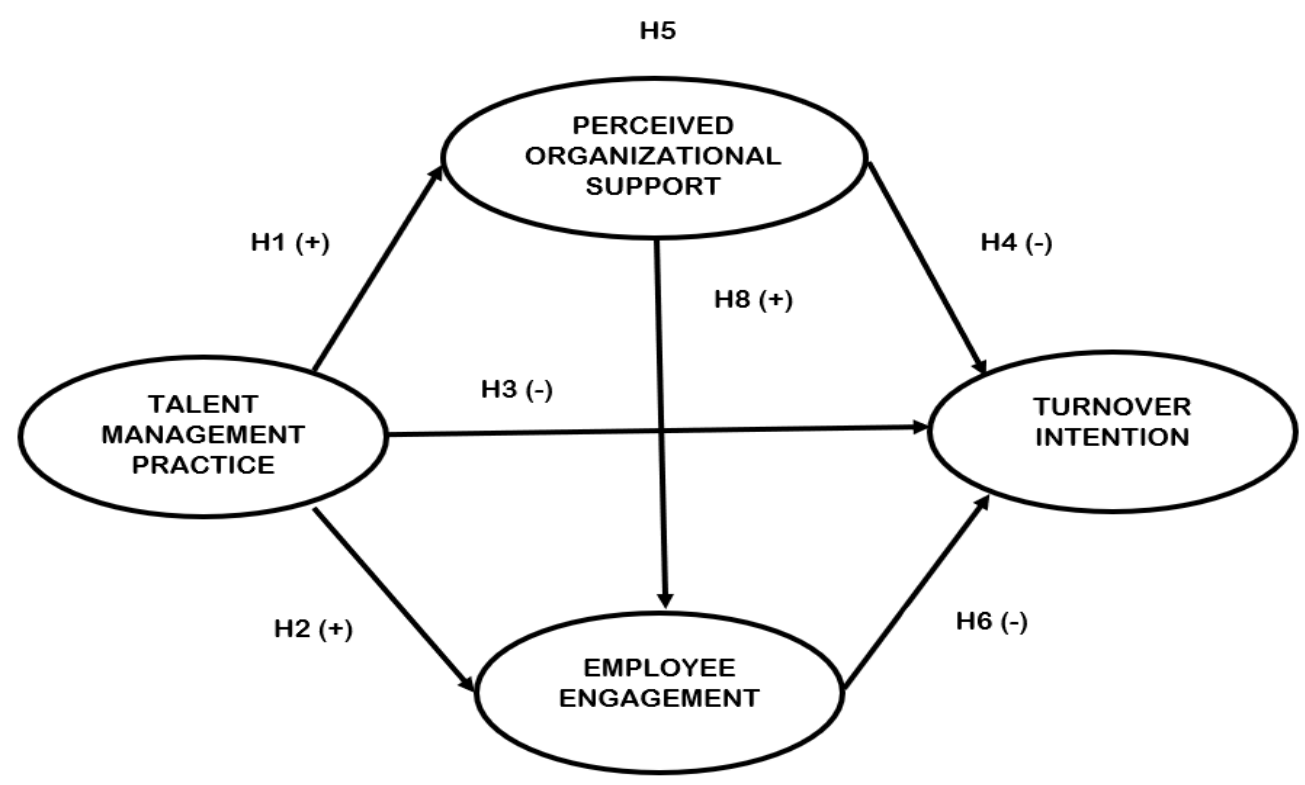

$\mathrm{H} 7$

Figure 1.

Integrated Conceptual Model 


\section{Wehelmina Rumawas}

\section{RESEARCH METHODS}

\section{Sample and Data Collection}

The data collection process involved interviewing Generation $Y$ employees at four government banks and two private banks in Manado City. The sampling approach of this study is a non-probability convenience sampling technique. A total of 200 questionnaires were distributed, 182 questionnaires were returned.

The researcher used the questionnaire survey method to collect data to test the research hypotheses. The survey instrument consisted of 63 questions designed to test various variables. The form contained questions about TMP, POS, EE, and TI. The proposed model and hypotheses were tested by Structural Equation Model (SEM) with SmartPLS software.

\section{Measures}

The Human Capital index of human Capital Institute Vurv Technology (2008), adapted from (Gupta 2019), was used to measure the perceived TMP of the organization. The index included 45 items and measured eight TMP techniques, including management commitment, talent review process, workforce planning, staffing, talent acquisition, talent development, performance management, and talent retention strategies. On a five-point scale ranging from "poor (1)" to "excellent (5)," respondents were asked to rate their organizations' existing TMP.

POS was measured using six items from the short form of POS scale (Park et al., 2016) adapted from Eisenberger et al., (1986) original scale. It was measured on a five-point Likert scale ranging from "strongly disagree (1)" to "strongly agree (5)".

Employee engagement was assessed using the short form of Utrecht Work Engagement Scale (UWES) (Schaufeli et al., 2006) adapted from Schaufeli et al. (2002). The UWES items are classified into three subscales, each of which reflects one of the underlying characteristics of engagement: Vigour ( 3 items), dedication ( 3 items), and absorption ( 3 items). All items are scored on a five-point Likert scale ranging from "strongly disagree (1)" to "strongly agree (5)".

The turnover intention was measured using three items from Madden et al. (1992). The items were rated on a five-point Likert scale ranging from "strongly disagree (1)" to "strongly agree (5)". 


\section{RESULTS AND DISCUSSION}

Respondents in this sample, $53.8 \%$, were female, and $46.2 \%$ were male. The majority, $44.5 \%$, were between $30-35$ years old, $37.4 \%$ were under 30 years old, and $18.1 \%$ were over 35 years old. The education level of the respondents, $18.8 \%$ had a diploma degree, $76.4 \%$ had an undergraduate degree, and $3.8 \%$ had a postgraduate degree.

\section{Measurement Model}

The measurement model can be assessed using reliability and validity. Composite reliability (CR) and Cronbach alpha are used to determine the model's reliability. According to Hair ef al. (2014), CR is acceptable if it exceeds 0.7. As shown in Table 1, Cronbach alphas for this study ranged from 0.872-0.958, all of which exceeds the recommended value of 0.7. the CR ranges from 0.921-0.965, exceeding the recommended level of 0.7.

Table 1

Test Results of Measurement Model in SEM

\begin{tabular}{|c|c|c|c|c|c|}
\hline Variable & Indicator & Factor loading & $\begin{array}{l}\text { Cronbach's } \\
\text { alpha }\end{array}$ & $\begin{array}{l}\text { Composite } \\
\text { reliability }\end{array}$ & AVE \\
\hline $\begin{array}{l}\text { Talent } \\
\text { Management } \\
\text { Practice }\end{array}$ & $\begin{array}{l}\text { TMP1 } \\
\text { TMP2 } \\
\text { TMP3 } \\
\text { TMP4 } \\
\text { TMP5 } \\
\text { TMP6 } \\
\text { TMP7 } \\
\text { TMP8 }\end{array}$ & $\begin{array}{l}0.865 \\
0.867 \\
0.877 \\
0.857 \\
0.888 \\
0.915 \\
0.898 \\
0.873\end{array}$ & 0.958 & 0.965 & 0.775 \\
\hline $\begin{array}{l}\text { Perceived } \\
\text { Organizational } \\
\text { Support }\end{array}$ & $\begin{array}{l}\text { POS1 } \\
\text { POS2 } \\
\text { POS3 } \\
\text { POS4 } \\
\text { POS5 } \\
\text { POS6 }\end{array}$ & $\begin{array}{l}0.900 \\
0.901 \\
0.870 \\
0.866 \\
0.898 \\
0.910\end{array}$ & 0.948 & 0.959 & 0.794 \\
\hline $\begin{array}{l}\text { Employee } \\
\text { Engagement }\end{array}$ & $\begin{array}{l}\text { EE1 } \\
\text { EE2 } \\
\text { EE3 }\end{array}$ & $\begin{array}{l}0.909 \\
0.874 \\
0.894\end{array}$ & 0.872 & 0.921 & 0.796 \\
\hline $\begin{array}{l}\text { Turnover } \\
\text { Intention }\end{array}$ & $\begin{array}{l}\text { TI1 } \\
\text { T12 } \\
\text { T13 }\end{array}$ & $\begin{array}{l}0.944 \\
0.929 \\
0.944\end{array}$ & 0.933 & 0.957 & 0.882 \\
\hline
\end{tabular}

The validity can be assessed using convergent validity and discriminant validity. Convergent validity is determined through factor loading and average variance extracted (AVE). As seen in Table 1, the factor loading of twenty items over four variables is greater than the recommended threshold of 0.7 (Hair et al., 2010). Each variable's AVE must be greater than 0.5 (Hair et al., 2014). The Fornell-Larcker criterion is used to determine discriminant validity. Fornell and Larcker (1981) recommend that the square root of each AVE of latent variables be 


\section{Wehelmina Rumawas}

employed. The AVE value should be greater than the correlations between latent variables. The square root of AVEs ((Table 2)) is more significant than their correlation coefficients with any construct.

\section{Table 2}

Fornell-Larcker Criterion

\begin{tabular}{ccccc}
\hline & TMP & POS & EE & TI \\
\hline TMP & $\mathbf{0 . 8 8 0}$ & & & \\
POS & 0.497 & $\mathbf{0 . 8 9 1}$ & & \\
EE & 0.573 & 0.691 & $\mathbf{0 . 8 9 2}$ & $\mathbf{0 . 9 3 9}$ \\
TI & -0.522 & -0.602 & -0.623 & \\
\hline
\end{tabular}

The validity can be assessed using convergent validity and discriminant validity. Convergent validity is determined through factor loading and average variance extracted (AVE). As seen in Table 1, the factor loading of twenty items over four variables is greater than the suggested threshold of 0.7 (Hair et al., 2010). Each variable's AVE must be greater than 0.5 (Hair et al., 2014). The Fornell-Larcker criterion is used to determine discriminant validity. Fornell and Larcker (1981) recommend that the square root of each AVE of latent variables be employed. The AVE value should be greater than the correlations between latent variables. The square root of AVEs ((Table 2)) was more significant than their correlation coefficients with any construct.

Table 2

Fornell-Larcker Criterion

\begin{tabular}{ccccc}
\hline & TMP & POS & EE & TI \\
\hline TMP & $\mathbf{0 . 8 8 0}$ & & & \\
POS & 0.497 & $\mathbf{0 . 8 9 1}$ & & \\
EE & 0.573 & 0.691 & $\mathbf{0 . 8 9 2}$ & $\mathbf{0 . 9 3 9}$ \\
TI & -0.522 & -0.602 & -0.623 & \\
\hline
\end{tabular}

\section{Structural Model}

The structural model can be assessed using the coefficient of determination $\left(R^{2}\right)$ and predictive relevance $\left(Q^{2}\right)$. The $R^{2}$ ranges for all endogenous variables demonstrate the extent to which each endogenous variable explains variance. $R^{2}$ values of $0.75,0.5$, and 0.25 are regarded as substantial, moderate, and weak, respectively (Hair et al., 2010). The results indicated that $R^{2}$ values of POS (0.247), EE (0.547), and TI $(0.471)$, respectively. According to Hair et al. (2014), $Q^{2}$ is an indicator of the predictive power of out-of-sample models or predictive relevance. The $Q^{2}$ value larger than o represents the model has sufficient predictive power. All Q2 values were more than 0, POS (0.188), EE (0.429), and TI (0.407), suggesting the model had predictive relevance. 
The variance inflation factor (VIF) was used to evaluate the presence of multicollinearity among variables. The results indicate VIF values of TMP (1.533), POS (1.971), and EE (2.209). All VIF resulting from the multicollinearity test was $<3.3$. They demonstrated that multicollinearity did not threaten this structural model and was free of common method bias (Kock, 2015).

\section{Table 3}

Result Structural Model

\begin{tabular}{|c|c|c|c|}
\hline Variable & Path Coefficient & T-Statistic & P-Value \\
\hline TMP -> POS & 0,497 & 6,169 & 0,000 \\
\hline TMP -> EE & 0,305 & 4,510 & 0,000 \\
\hline TMP -> TI & $-0,202$ & 2,156 & 0,032 \\
\hline POS -> TI & $-0,290$ & 2,636 & 0,009 \\
\hline TMP -> POS -> TI & $-0,144$ & 2,519 & 0,012 \\
\hline EE ->TI & $-0,307$ & 2,560 & 0,011 \\
\hline TMP -> EE -> TI & $-0,094$ & 2,382 & 0,018 \\
\hline POS -> EE & 0,540 & 8,463 & 0,000 \\
\hline
\end{tabular}

\section{Hypotheses Testing}

Based on the structural equation model analysis result (Table 3), the following hypothesis testing results are as follows: TMP to POS $(\beta=0.497, P=0.000)$, because $p \leq 0.05$, then TMP has a positive and significant effect on POS. This result shows that there is empirical evidence to support Hypothesis 1. TMP to EE $(\beta=0.305, P=0.000)$, because $p \leq 0.05$, then TMP has a positive and significant effect on EE. This result shows that there is empirical evidence to support Hypothesis 2. TMP to TI ( $\beta=-0.202, P=0.032$ ), because $p \leq 0.05$, TMP has a negative and significant effect on TI. This result shows that there is empirical evidence to support Hypothesis 3. POS to TI $(\beta=-0.290$, $P=0.009$ ), because $p \leq 0.05$, POS has a negative and significant effect on $T I$. This result shows that there is empirical evidence to support Hypothesis 4. TMP to TI through POS ( $\beta=-0.144, P=0.012)$, because $p \leq 0.05$, POS mediates the relationships between TMP and TI. This result shows that there is empirical evidence to reject Hypothesis 5. EE to Tl $(\beta=-0.307, P=0.011)$, because $p \leq 0.05$, EE has a negative and significant effect on TI. This result shows there is empirical evidence to support Hypothesis 6. TMP to TI through EE ( $\beta=-0.094, P=0.018)$, because $p \leq 0.05$, EE mediates the relationships between TMP and TI. This result shows that there is empirical evidence to support Hypothesis 7. POS to $E E(\beta=0.540, P=0.000)$, because $p \leq 0.05$, POS has a positive and significant effect on EE. This result shows that there is empirical evidence to support Hypothesis 8.

\section{Discussion}

The purpose of this study was to investigate whether there is a correlation between perceived talent management practices, organizational support, employee engagement, and Generation Y's intention to leave their current jobs. The findings are interpreted in terms of the research hypothesis. 


\section{Wehelmina Rumawas}

The results showed a significant positive relationship between the Generation Y employees' perception of the organization's TMP and POS. These findings corroborate prior research (DU Plessis et al., 2015; Gupta, 2019), indicating that Generation Y employees' perceptions of talent management practices predict POS. This finding demonstrates that employees' perceptions are oriented towards optimizing talents and recognizing their contributions. The employees' opinion that the corporation practices are focused on optimizing talent and willing to invest in it would result in the perception that the organization values their contributions and cares about their general well-being.

The result suggested a significant positive relationship between Generation Y employees' perception of the organization's TMP and EE. This result confirms the findings of Bui and Chang (2018) that the Generation Y employee's perception of TMP is an antecedent of EE. The finding indicates that how employees perceive the organization's talent management practices affects how engaged employees are. This result also shows that the higher the employee's perception of the organization's talent management practices, the higher the employee's involvement in the organization.

The findings indicated a statistically significant negative association between Generation $Y$ employees' perceptions of their TMP and turnover intention. This study's outcome corroborates the findings of multiple other research establishing a negative correlation between TMP and TI (Bui and Chang, 2018; Du Plessis et al., 2015; Gupta, 2019). This finding indicates that a positive view of the TMP application at an organization correlates with a low turnover intention. The embrace of Talent Management principles by a company and the investment of resources to these practices will therefore contribute to the acquisition and retention of high performers.

This study established a substantial negative correlation between POS and Generation Y employees' turnover intention. Employees perceive that the organization has treated them positively so that their intention to leave is reduced. This finding is consistent with earlier research indicating that employees with a high POS are less inclined to seek out and accept different jobs (Du Plessis et al., 2015; Gupta, 2019; Joo et al., 2015). This research suggests that employees who believe their employer genuinely cares about them and supports them are less likely to seek alternative employment.

The result of the structural equation model analysis demonstrated that POS fully mediated the correlation between perceived TMP and turnover intention. These results indicate that talent 
management practices and positive support from the organization will reduce employee turnover intentions. These results contradict (2015) and Gupta (2019), which confirmed that POS does not mediate organizational TMP and turnover intention.

Hypothesis 6: There is a negative correlation between Generation Y employees' perceptions of EE and TI.

The results showed a significant negative relationship between EE and Generation Y employees' turnover intention. These results align with numerous studies (Bui and Chang, 2018; Kim and Hyun, 2017; Memon et al., 2020; Sibiya et al., 2014), which revealed a negative relationship between EE and TI. This result indicates that employees with strong work engagement are more likely to have reduced turnover intention. Thus, engaged employees tend to be satisfied, feel more committed to the organization, and are less likely to quit their jobs.

The structural equation model analysis established that EE significantly mediated the relationship between perceived TMP and turnover intention. These results indicate that talent management practices with strong work engagement are more likely to have reduced turnover intention. This result confirms the results of Bui and Chang (2018), which revealed that EE is a mediator of organizational TMP and turnover intention.

The analysis suggested that POS and EE have a considerable positive correlation. When perceived organizational support is high, employees show more involvement to work. The findings corroborate previous research that established a positive link between POS and EE (Musenze et al., 2020; Nazir and Islam, 2017). The result shows that employees who perceive higher organizational support are more likely to reciprocate with enhanced levels of engagement at work.

\section{CONCLUSION}

This study explores and understands the impact of perceived TMP on Generation Y employees' intention to leave their jobs. This study's findings reveal that TMP has a significant positive effect on POS and EE. Likewise, TMP, POS, and EE have a significant negative effect on Generation Y employees' turnover intention. POS has a significant positive effect on EE. The research finding also shows that the indirect relationship between TMP and TI through the mediation of POS and EE has a significant negative effect.

The results of this study have implications for both theory and practice. In theory, this study establishes a model framework to comprehend the causal relationship between the variables and Generation Y employees' intention to leave an organization. Moreover, this research 


\section{Wehelmina Rumawas}

contributes to TMP perceptions amongst Generation Y employees about other constructs. The results of this study have practical implications for human resource development managers in banking industries. First, the research establishes a framework for management to comprehend how the TMP, POS, and EE affect Generation Y employees' perceptions and intention to leave. Second, by focusing on Talent Management practices, this study provides managers with a strategy for developing and retaining talented Generation $Y$ employees. Third, an organization's focus on implementing TMP in influencing turnover intention may not occur if the organization has indicated a lack of support and engagement at work.

The research had several limitations. First, data were collected from six government and private banks in Manado City and only focussed on the perception of Generation $Y$ employees, limiting the generalizability of the result. Therefore, further study might be more government and private banks and focus on all generations. Second, this study only examined POS and EE as the mediator. Future research could provide a complete explanation of this relationship by examining other mediators.

\section{Acknowledgments}

This research was supported by the Institute for Research and Community Service (LPPM), Sam Ratulangi University Manado-Indonesia. [Grant number: 572/UN12.13/LT/2021].

\section{REFERENCES}

Akgunduz, Y., Alkan, C. and Gök, Ö.A. 2018. Perceived organizational support, employee creativity and proactive personality: The mediating effect of meaning of work. Journal of Hospitality and Tourism Management, 34: 105-114.

Alias, N.E., Nor, N.M. and Hassan, R. 2016. Proceedings of the 1st AAGBS International Conference on Business Management 2014 (AiCoBM 2014). Proceedings of the 1st AAGBS International Conference on Business Management 2014 (AiCoBM 2014), 2014(AiCoBM 2014): 101-115.

Allen, D.G., Shore, L.M. and Griffeth, R.W. 2003. The Role of Perceived Organizational Support and Supportive Human Resource Practices in the Turnover Process. Journal of Management, 29(1): 99-118.

Anlesinya, A., Amponsah-Tawiah, K. and Dartey-Baah, K. 2019. Talent management research in Africa: towards multilevel model and research agenda. African Journal of Economic and Management Studies, 10(4): 440-457.

Basset, B. 2008. Working With Generation Y. In: Office PRO:16-19.

Bui, L.T.T. and Chang, Y. 2018. Talent management and turnover intention: focus on Danang 
city government in Vietnam. International Review of Public Administration, 23(4): 219-236.

Cao, L., Hirschi, A. and Deller, J. 2014. Perceived organizational support and intention to stay in host countries among self-initiated expatriates: The role of career satisfaction and networks. International Journal of Human Resource Management, 25(14): 2013-2032.

Claus, L. 2019. HR disruption-Time already to reinvent talent management. BRQ Business Research Quarterly, 22(3): 207-215.

Eisenberger, R., Huntington, R., Hutchison, S. and Sowa, D. 1986. Eisenberger 1986 JAppPsychol POS original article. Journal of Applied Psychology, 71 (3): 500-507.

Fornell, C. and Larcker, D.F. 1981. Evaluating Structural Equation Models with Unobservable Variables and Measurement Error. Journal of Marketing Research, 18(1): 39-50.

Ghosh, P., Satyawadi, R., Joshi, J.P. and Shadman, M. 2013. Who stays with you? Factors predicting employees' intention to stay. International Journal of Organizational Analysis, $21(3): 288-312$.

Guchait, P., Cho, S. and Meurs, J.A. 2015. Psychological Contracts, Perceived Organizational and Supervisor Support: Investigating the Impact on Intent to Leave Among Hospitality Employees in India. Journal of Human Resources in Hospitality and Tourism, 14(3): 290-315.

Gupta, V. 2019. Talent management dimensions and their relationship with retention of Generation-Y employees in the hospitality industry. International Journal of Contemporary Hospitality Management, 31 (10): 4150-4169.

Guthridge, M., Komm, A.B. and Lawson, E. 2008. Making talent a strategic priority. McKinsey Quarterly, (1).

Hair, J.F., Black, W., Babin, B. and Anderson, R. 2010. Multivariate data analysis.

Hom, P.W. 2004. Labor Turnover. Encyclopedia of Applied Psychology, Three-Volume Set, 2: 497-505.

Hughes, J.C. and Rog, E. 2008. Talent management: A strategy for improving employee recruitment, retention and engagement within hospitality organizations. International Journal of Contemporary Hospitality Management, 20(7): 743-757.

Islam, T., Khan, S. ur R., Ahmad, U.N.U.B. and Ahmed, I. 2013. Organizational learning culture and leader-member exchange quality: The way to enhance organizational commitment and reduce turnover intentions. Learning Organization, 20(4-5): 322-337.

Joo, B.K.B., Hahn, H.J. and Petersonb, S.L. 2015. Turnover intention: The effects of core selfevaluations, proactive personality, perceived organizational support, developmental feedback, and job complexity. Human Resource Development International, 18(2): $116-$ 130. 


\section{Wehelmina Rumawas}

Kim, W. and Hyun, Y.S. 2017. Article information: Running head: Work Engagement Between Personal Resources and Turnover Intention. European Journal of Training and Development, 41 (8): 705-721.

Kock, N. 2015. Common method bias in PLS-SEM: A full collinearity assessment approach. International Journal of e-Collaboration, 11(4): 1-10.

León, F.R. and García-Saavedra, J.L. 2019. Testing three assumptions of talent management about the motivation to quit in Lima, Peru. International Journal of Human Resource Management, 0(0): 1-20.

Madden, T.J., Ellen, P.S. and Ajzen, I. 1992. A Comparison of the Theory of Planned Behavior and the Theory of Reasoned Action. Personality and Social Psychology Bulletin, 18(1): 3-9.

Memon, M.A., Salleh, R., Mirza, M.Z., Cheah, J.H., Ting, H. and Ahmad, M.S. 2020. Performance appraisal satisfaction and turnover intention: The mediating role of work engagement. Management Decision, 58(6): 1053-1066.

Musenze, I.A., Mayende, T.S., Wampande, A.J., Kasango, J. and Emojong, O.R. 2020. Mechanism between perceived organizational support and work engagement: explanatory role of self-efficacy. Journal of Economic and Administrative Sciences, ahead-of-p(ahead-of-print).

Naim, M.F. and Lenka, U. 2018. Development and retention of Generation Y employees: a conceptual framework. Employee Relations, 40(2): 433-455.

Nazir, O. and Islam, J.U. 2017. Enhancing organizational commitment and employee performance through employee engagement: An empirical check. South Asian Journal of Business Studies, 6(1): 98-114.

Park, J.H., Newman, A., Zhang, L., Wu, C. and Hooke, A. 2016. Mentoring functions and turnover intention: the mediating role of perceived organizational support. International Journal of Human Resource Management, 27(11): 1173-1191.

Du Plessis, L., Barkhuizen, N., Stanz, K. and Schutte, N. 2015. The management side of talent: Causal implications for the retention of generation y employees. Journal of Applied Business Research, 31 (5): 1767-1780.

Riendl, R. 2007. Growing Talent at Edwards Lifesiences. Training \& Development: 38-41.

Saks, A.M. 2006. Antecedents and consequences of employee engagement. Journal of Managerial Psychology, 21 (7): 600-619.

Sandhya, S. and Sulphey, M. 2021. Influence of empowerment, psychological contract and employee engagement on voluntary turnover intentions. International Journal of Productivity and Performance Management, 70(2): 325-349. 
Schaufeli, W.B., Bakker, A.B. and Salanova, M. 2006. The measurement of work engagement with a short questionnaire: A cross-national study. Educational and Psychological Measurement, 66(4): 701-716.

Schaufeli, W.B., Salanova, M., Gonzalez-Roma, V. and Bakker, A.B. 2002. Measurement of Engagement and Burnout: A Two Sample of Confirmatory Factor Analytic Approach. Journal of Happiness Studies, 3: 71-92.

Sibiya, M., Buitendach, J.H., Kanengoni, H. and Bobat, S. 2014. The prediction of turnover intention by means of employee engagement and demographic variables in a telecommunications organisation. Journal of Psychology in Africa, 24(2): 131-143.

Suliman, A.M. and Al Obaidli, H. 2011. Organizational climate and turnover in Islamic banking in the UAE. International Journal of Islamic and Middle Eastern Finance and Management, $4(4): 308-324$.

Wang, Y., Jiang, N., Zhang, H. and Liu, Z. 2020. Organizational justice, burnout, and turnover intention of social workers in China. Journal of Social Work: 1-20.

Whitener, E.M. 2001. Do "high commitment" human resource practices affect employee commitment? Journal of Management, 27(5): 515-535.

Zainee, I.A. and Puteh, F. 2020. Corporate social responsibility impact on talent retention among Generation Y. Revista de Gestão, 27(4): 369-392. 